\title{
PERLINDUNGAN HUKUM TERHADAP ANAK YANG BERKONFLIK DENGAN HUKUM
}

\author{
Widya Romasindah Aidy \\ widya.romasindah@ubharajaya.ac.id \\ Fakultas Hukum Universitas Bhayangkara Jakarta Raya
}

\begin{abstract}
ABSTRAK
Tujuan penulis meneliti mengenai bagaimanakah pelaksanaan pembinaan anak yang berkonflik dengan hukum sesuai prinsip yang terdapat dalam Standard Minimum Rules for The Administration of Juveniles Justice/Beijing Rules dan The United Nations Rules for The Protection of Juvenile Deprived of Liberty/JDL, adalah untuk mendeskripsikan sejauhmana pelaksanaan dan pembinaan terhadap anak yang berkonflik dengan hukum sesuai prinsip yang terdapat dalam Standard Minimum Rules for The Administration of Juveniles Justice/Beijing Rules dan The United Nations Rules for The Protection of Juvenile Deprived of Liberty/JDL dan untuk mengidentifikasi kendala-kendala yang dihadapi dalam pelaksanaan pembinaan anak berkonflik dengan hukum. Jenis penelitian ini merupakan penelitian hukum yuridis normatif dan yuridis empiris dengan karakteristik deskriptif yang bersumber pada data primer dan data sekunder. Sistem peradilan pidana anak telah mengkonstruksi hak-hak anak yang berhadapan dengan hukum $(\mathrm{ABH})$ yaitu dengan tidak lagi diposisikannya anak sebagai objek dengan tujuan agar dapat terwujud peradilan yang benar-benar menjamin pelindungan kepentingan terbaik terhadap anak yang berhadapan dengan hukum sebagai penerus bangsa. Dalam penerapan prinsip mengutamakan kepentingan terbaik bagi anak, diperlukan proses penyelesaian perkara anak di luar mekanisme pidana atau biasa disebut diversi, dengan pendekatan keadilan restorasi. Mekanisme diversi dilakukan dalam semua jenjang peradilan pidana anak (dimulai dalam tahap penyelidikan/penyidikan di Kepolisian, diversi bisa juga dilakukan pada saat penuntutan, pada saat di Pengadilan, dan diversi bisa dilakukan pada saat tahap pelaksanaan putusan).
\end{abstract}

Kata Kunci: Anak, Diversi, Sistem Peradilan Anak

\begin{abstract}
The author's purpose was to investigate how the implementation of coaching children in conflict with the law according to the principles contained in the Standard Minimum Rules for the Administration of Juveniles Justice / Beijing Rules and The United Nations Rules for The Protection of Juvenile deprived of Liberty/JDL, was to describe the extent of implementation and coaching against children in conflict with the law according to the principles contained in the Standard Minimum Rules for the Administration of Juveniles Justice / Beijing Rules
\end{abstract}


and the United Nations Rules for the Protection of Juvenile deprived of Liberty/JDL and to identify the obstacles encountered in the implementation of coaching children in conflict with the law. This research is a normative legal research and emperical legal research with descriptive characteristics that originates in the primary data and secondary data. Juvenile justice system have constructed the rights of children in conflict with the law $(A B H)$ is by no longer position child as an object in order for justice to be realized completely guarantee the protection of the best interests of the children in conflict with the law as the nation's future. In applying the principle that the best interest of the child, the child process is required for settling disputes outside the criminal mechanisms or so-called diversion, with the approach of the restoration of justice. Diversion mechanism is done in all levels of the juvenile criminal justice (start in the investigation stage / Police investigation, diversion can also be done at the time of prosecution, when in court, and diversion can be done during the implementation phase of the decision).

Keywords: Child, Diversion, Juvenile justice system.

\section{PENDAHULUAN}

Kehadiran anak dalam kehidupan keluarga sangat dinantikan. Belum lengkap ikatan perkawinan jika belum atau tidak dikarunia anak. Berbagai ikhtiar dilakukan oleh pasangan suami isteri untuk mempunyai anak. Hal ini menggambarkan betapa penting dan berartinya anak bagi keluarga dan dalam scala besar juga untuk negara. ${ }^{1}$

Mengingat anak mempunyai peran penting dalam kehidupan, maka permasalahan anak yang pada awalnya merupakan masalah pribadi yaitu masalah hubungan antara orang tua dengan anaknya, lambat-laun permasalahan anak diletakkan sebagai persoalan publik dimana Pemerintah harus hadir melalui berbagai instrumen regulasinya untuk mengatur semua kepentingan hukum terhadap anak sekaligus juga untuk menjamin keberlangsungan anak secara baik dan berguna. Peran pemerintah melalui regulasi ini mengingat anak merupakan kelompok yang rawan dan rentan dieksploitasi karena secara fisik maupun mental anak tetapi tidak sedikit juga telah berkonflik

\footnotetext{
${ }^{1}$ Republik Indonesia, Undang-Undang Nomor 35 tahun 2014 Tentang Perubahan Atas UndangUndang Nomor 23 tahun 2002 Tentang Perlindungan Anak. Dalam Konsideran huruf c disebutkan, "bahwa anak sebagai tunas, potensi, dan generasi muda penerus cita-cita perjuangan bangsa memiliki peran strategis, ciri, dan sifat khusus sehingga wajib dilindungi dari segala bentuk perlakuan tidak manusiawi yang mengakibatkan terjadinya pelanggaran hak asasi manusia"
} 
Menteri Pemberdayaan Perempuan dan Perlindungan Anak Yohana Yembise mengaku prihatin dengan meningkatnya jumlah anak yang berhadapan dengan hukum. Menurut data Anak Berkonflik Hukum (ABH) dari Direktorat Jenderal Pemasyarakatan, Kementerian Hukum dan HAM, pada bulan Maret 2015 jumlah penghuni Lapas sebanyak 3.559 anak yang terdiri dari tahanan anak sebanyak 894 anak dan jumlah napi anak sebanyak 2.665 anak. $^{2}$

Salah satu bentuk perlindungan tersebut dengan memberikan suatu intervensi hukum, untuk meminta pertanggungjawaban terhadap anak-anak yang berkonflik dengan hukum (sebagai pelaku tindak pidana). Permasalahannya adalah apakah bentuk pertanggungjawaban si anak itu telah dilakukan dengan memprioritaskan kepentingan terbaik si anak?

Perkembangan anak tidak terlepas dari perkembangan lingkungan tempat dimana anak berada. Lingkungan yang dimaksud tidak hanya keluarga inti, tetapi juga saudara, sekolah, tetangga maupun teman-teman. Koji Yamashita, sebagaimana yang dikutip oleh Apong Herlina menyatakan:

"Anak belajar dari cara mereka dibesarkan. Kalau mereka dibesarkan dengan kritikan maka mereka akan belajar untuk mencari kesalahan orang lain, kalau mereka dibesarkan dengan permusuhan, maka mereka akan belajar berkelahi. Jika mereka dibesarkan dengan toleransi, maka mereka akan belajar untuk bersabar, kalau mereka dibesarkan dengan perlakuan adil maka mereka akan belajar untuk menghargai",3

Upaya untuk memberikan perlindungan ini dilakukan baik oleh orang tua maupun oleh Pemerintah. Upaya ini sering dihadapkan pada permasalahan dan tantangan dalam masyarakat yang dijumpai berupa penyimpangan perilaku di kalangan anak, bahkan ada anak yang melakukan perbuatan melanggar hukum. Kecenderungan meningkatnya tindakan kriminal oleh pelaku usia muda, mendorong kita untuk menangani permasalahan ini sekaligus memberikan perlindungan terhadap mereka. Anak yang melakukan kejahatan akan mengalami

2 Menteri Pemberdayaan Perempuan dan Perlindungan Anak Yohana Yembise, Jumlah Anak Berhadapan Dengan Hukum Meningkat, Antaranews.com, Selasa, 28 April 2015.

${ }^{3}$ Apong Herlina, Et. Al., "Perlindungan Terhadap Anak Yang Berhadapan Dengan Hukum, Manual Pelatihan Untuk Polisi”, (Jakarta: UNICEF, 2004), hlm.182. 
proses peradilan pidana yang dapat diartikan secara luas yaitu meliputi sebelum di sidang peradilan, selama sidang peradilan dan setelah sidang peradian. Selama proses ini tidak jarang si anak harus ditahan (artinya anak belum memiliki ketetapan hukum atas perkaranya).

Telah banyak instrumen hukum yang memuat ketentuan mengenai perlindungan terhadap hak asasi manusia, khususnya hak-hak anak. Misalnya Undang-Undang Nomor 3 Tahun 1997 tentang Peradilan Anak, Undang-Undang Nomor 39 Tahun 1999 tentang Hak Asasi Manusia dan Undang-Undang Nomor 35 Tahun 2014 tentang Perubahan Atas Undang-Undang Nomor 23 Tahun 2002 tentang Perlindungan Anak serta Undang-Undang Nomor 11 Tahun 2012 tentang Sistem Peradilan Pidana Anak.

1. Perlindungan anak juga menjadi perhatian dunia hal ini terdapat dalam instrumen-instrumen Internasional, antara lain Deklarasi Jenewa tentang Hak-hak Anak tahun 1954 yang kemudian dikukuhkan dalam Resolusi Majelis Umum PBB No. 1386 (XIV) tanggal 20 Nopember 1959 mengenai Declaration of The Rights of The Child, Resolusi majelis umum PBB 40/33 tanggal 29 Nopember 1985 mengenai United Nations Standard Minimum Rules for The Administration of Juvenile Justice (The Beijing Rules), dan Resolusi majelis umum PBB 44/25 tanggal 20 Nopember 1989 mengenai Convention of The Rights of The Child. Berbagai dokumen internasional di atas jelas merupakan refleksi dari kesadaran dan keprihatinan masyarakat Internasional akan perlunya perlindungan terhadap keadaan buruk atau menyedihkan yang menimpa anak-anak di seluruh dunia.

\section{I.1 Rumusan Masalah}

Berdasarkan permasalahan diatas, pertanyaan penelitian yang akan di bahas:

1. Bagaimanakah pelaksanaan pembinaan anak yang berkonflik dengan hukum sesuai prinsip yang terdapat dalam Standard Minimum Rules for The Administration of Juveniles Justice/Beijing Rules dan The United Nations Rules for The Protection of Juvenile Deprived of Liberty/ JDL? 
2. Apa saja kendala-kendala yang dihadapi dalam pelaksanaan pembinaan anak yang berkonflik dengan hukum?

\section{I.2 Kerangka Teoritis}

Secara skematis kerangka teoritis yang penulis gunakan dalam penelitian ini, dapat dideskripsikan sebagai berikut:

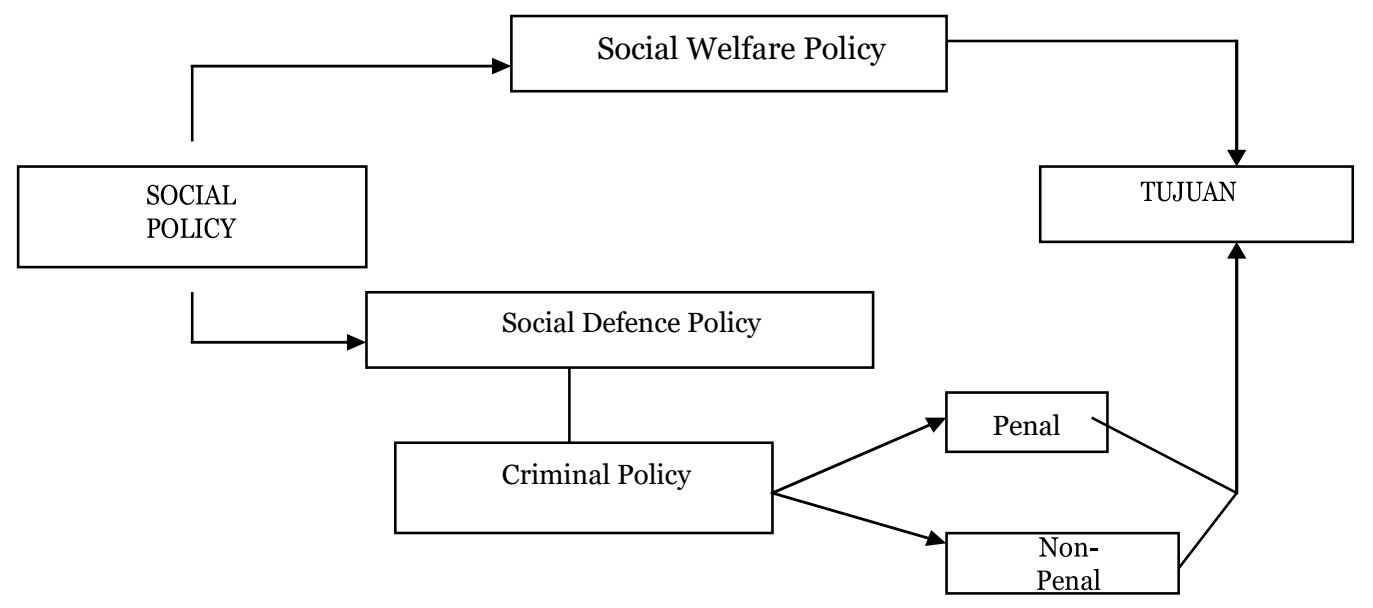

Kebijakan kriminal adalah merupakan bagian dari kebijakan sosial yang bertujuan untuk mencapai kesejahteraan masyarakat. Usaha untuk mencapai kesejahteraan masyarakat dalam kebijakan kriminal itu dapat dilakukan melalui jalur "penal" dan "non-penal"; Jalur "penal" diarahkan kepada penggunaan hukum pidana setelah terjadinya kejahatan. Sedangkan jalur "non-penal" lebih diarahkan kepada usaha mencari faktor penyebab terjadinya kejahatan. Dalam hal ini yang diupayakan adalah menghilangkan sebab-sebab timbulnya kejahatan, yang antara lain adalah karena tidak efektifnya hukuman yang diterapkan dan cara pelaksanaannya, disamping faktor-faktor lainnya.

Menurut Satjipto Rahardjo, adanya masing-masing lembaga penegak hukum yang berbeda fungsi, dalam pelaksanaanya memerlukan pengorganisasian dalam mencapai tujuan yang sama dalam kerangka peradilan pidana. Proses pengorganisasian tersebut pada dasarnya merupakan kegiatan manajemen, dengan memanfaatkan seluruh sumber daya 
lembaga melalui orang, teknik dan informasi yang dijalankan dalam kerangka struktur organisasi. ${ }^{4}$ Pengorganisasian fungsi penegak hukum pidana oleh Muladi, di pandang sangat penting karena:

“......... penegakkan hukum pidana pada hakekatnya interdepence (unsurnya interaksi, interkoneksi dan interdependensi) antar adresat hukum, yakni para penegak hukum dan masyarakat disamping faktor hukumnya sendiri dan sarana penunjangnya. Dalam hal ini ruang lingkup penegakkan hukum harus dilihat secara luas yang mencakup baik onrecht in actu maupun onrecht in potentie, mencakup tindakan kuratif, represif dan kuratif'. ${ }^{5}$

Pada hakekatnya penegakkan hukum merupakan proses penyerasian antara nilainilai, kaidah-kaidah dan pola prilaku nyata yang bertujuan untuk mencapai kedamaian. Oleh karena itu tugas utama penegakkan hukum adalah mencapai keadilan. ${ }^{6}$ Dengan demikian sistem peradilan pidana pada hakikatnya merupakan suatu proses penegakkan hukum pidana baik substantif maupun hukum acara pidana karena perundang-undangan pidana itu pada dasarnya merupakan penegakkan hukum pidana in abstracto yang akan diwujudkan dalam penegakkan hukum in concreto. $^{7}$

\section{I.3 Metode Penelitian}

Penelitian ini merupakan penelitian yuridis normatif dan empiris. Karakteristik penelitian ini adalah bersifat deskriptif, yaitu suatu tipe penelitian yang berusaha memberikan gambaran dan penjelasan tentang implementasi perlindungan hukum terhadap anak dalam hal ini perlindungan hak-hak anak sebagai tersangka tindak pidana (pelaku kejahatan) dan sumber data dalam penelitian ini merupakan data primer yaitu data yang di peroleh secara langsung dari institusi Kepolisian Resor Jakarta Selatan.

\footnotetext{
${ }^{4}$ Satjipto Rahardjo, "Keadaan dan permasalahan Penegakan Hukum Dewasa ini, Majalah Masalahmasalah Hukum", (Semarang: UNDIP, No.4 Tahun XIII, 1983), hlm.16

${ }^{5}$ Muladi, "Penegakan Hukum dan Keadilan melalui Upaya Peraturan Hukum", Makalah dalam Seminar Penegakan Hukum dan Masalahnya, (Semarang: Unissula, 1988), hlm.2

${ }^{6}$ Ibid., hlm.1

${ }^{7}$ Muladi dan Barda Nawawi Arief, “Teor-teori dan Kebijakan Pidana”, (Bandung: Alumni, 1998), hlm.197
} 


\section{PEMBAHASAN}

\section{II.1 Konsep Tujuan Hukum}

Hukum sebenarnya adalah alat dan bukan tujuan. Yang mempunyai tujuan adalah manusia. Akan tetapi karena manusia sebagai anggota masyarakat tidak mungkin dipisahkan dengan hukum, maka yang dimaksud tujuan hukum manusia dengan hukum sebagai alat untuk mencapai tujuan itu. ${ }^{8}$

Mengenai tujuan hukum terdapat beberapa pendapat atau teori namun dari berbagai teori tersebut, apabila diiventarisasi hanyalah terdapat dua teori yaitu teori etis dan teori utilitas. Kedua teori tersebut juga merupakan landasan dari teori atau pendapat lainya, dan teori lainya itu merupakan varian atau kombinasi dari teori etis dan atau teori utilitas. ${ }^{9}$

Menurut Mochtar Kusumaatmadja dan Arief Sidarta menyatakan bahwa tujuan hukum tidak bisa dilepaskan dari tujuan akhir hidup bermasyarakat yang tidak dapat dilepaskan dari nilai-nilai dan falsafah hidup yang menjadi dasar hidup masyarakat itu, yang akhirnya bermuara pada keadilan. ${ }^{10}$

\section{II.2 Konsep Perlindungan Hukum Terhadap Anak}

Menurut Pasal 1 ayat (1) Undang-Undang Nomor 35 Tahun 2014 tentang Perubahan Atas Undang-Undang Nomor 23 Tahun 2002 tentang Perlindungan Anak, anak adalah seseorang yang belum berusia 18 tahun, termasuk anak yang masih dalam kandungan. Kemudian pada Pasal 1 ayat (3) dan Pasal 20 UndangUndang Nomor 11 Tahun 2012 tentang Sistem Peradilan Pidana, dirumuskan: 1). Batas umur anak yang berhadapan hukum dapat diajukan ke Sidang Pengadilan Anak adalah sekurang-kurangnya 12 tahun tetapi belum mencapai umur 18 tahun dan belum pemah kawin, dan 2). Dalam hal anak melakukan tindak pidana pada batas umur sebagaimana dimaksud dalam Pasal 20 bahwa Anak yang berhadapan hukum sebelum genap berumur 18 tahun dan diajukan ke sidang pengadilan setelah

\footnotetext{
${ }^{8}$ Tim Pengajar PIH-FH-UNPAR, Pengantar Ilmu Hukum, (Bandung: UNPAR, 1995), hlm.36

${ }^{9}$ Sjachran Basah, Tiga Tulisan Tentang Hukum, (Bandung: Armico, 1985), hlm.8

${ }^{10}$ Mochtar Kusumaatmadja dan Arief Sidarta, "Pengantar Ilmu Hukum Suatu Pengenalan Pertama Ruang lingkup Berlakunya Ilmu Hukum”, (Bandung: Alumni, 2000), hlm.52
} 
anak tersebut telah melampaui batas umur 18 tahun, tetapi belum mencapai umur 21 tahun, anak tetap diajukan ke sidang anak.

Apabila ditinjau dari segi sosiologi, batasan umur seseorang disebut anak menurut Dellyana adalah: "Mereka yang belum dewasa dan yang menjadi dewasa karena peraturan tertentu (mental, fisik masih belum dewasa). Selain itu anak disini meliputi anak sebagai pelaku korban dan pengamat/saksi. Masing-masing mempunyai hak untuk tidak menjadi korban dalam proses peradilan pidana tertentu".

Perlindungan hukum pada anak yang bersifat yuridis pada dasarnya menyangkut perlindungan hukum yang diberikan pada anak baik di bidang hukum tertulis maupun hukum adat yang menjamin perlindungan anak sesuai dengan kebutuhannya agar mereka dapat menikmati hak-haknya dengan baik. ${ }^{11}$ Di telaah dari segi sifatnya, perlindungan anak dibagi menjadi 2 (dua), yaitu: a. Bersifat yuridis, yaitu meliputi perlindungan anak dalam bidang: hukum publik dan hukum keperdataan; b. Bersifat non yuridis meliputi perlindungan dalam bidang sosial, bidang kesehatan, dan bidang pendidikan. ${ }^{12}$

\section{II.3 Arah dan Tujuan Sistem Peradilan Pidana Anak}

Sejak berlakunya Undang-Undang Nomor 11 Tahun 2012 tentang Sistem Peradilan Pidana Anak yang biasa disingkat dengan SPPA, yang secara resmi menggantikan Undang-Undang Nomor 3 Tahun 1997 tentang Pengadilan Anak, maka terjadilah "Era baru" perubahan paradigma hukum dalam peradilan pidana anak dari yang dulunya bersifat absolut dan masih menggunakan pendekatan paradigma hukum lama yang selalu mengedepankan bahwa setiap anak yang melakukan perbuatan (pidana) harus dibalas dengan hukuman yang setimpal atau kita kenal dengan istilah "hak untuk membalas secara setimpal” (ius talionis), dimana pendekatan tersebut tidak jauh berbeda dengan perlakuan terhadap orang dewasa yang melakukan tindak pidana, berubah dengan pendekatan sistem hukum

\footnotetext{
11 Made Sadhi Astuti, 'Pemidanaan Terhadap Anak Sebagai Pelaku Tindak Pidana”, hlm.1

12 Irma Setyowati Soemitro, "Aspek Hukum Perlindungan Anak", (Jakarta: Bina Aksara, 1990), hlm. 130
} 
yang lebih humanis yang lebih mengutamakan pendekatan keadilan restoratif (restorative justice). Menurut Toni Marshal keadilan restoratif merupakan suatu proses dimana semua pihak yang terlibat dalam suatu tindak pidana tertentu, secara bersama-sama memecahkan masalah bagaimana menangani akibat dimasa yang akan datang. Menurut UU SPPA dalam Pasal 1 angka (6) bahwa pendekatan keadilan restoratif adalah penyelesaian perkara tindak pidana dengan melibatkan pelaku, korban, keluarga pelaku/ korban, dan pihak lain yang terkait untuk bersamasama mencari penyelesaian yang adil dengan menekankan pemulihan kembali kepada pada keadaan semula, dan bukanlah pembalasan.

Seorang anak (pelaku) yang diusianya yang masih sangat muda tetapi sudah berani melakukan perbuatan yang melanggar hukum (melakukan tindak pidana), pada dasarnya anak tersebut bukanlah seorang anak yang "Jahat" sehingga kita tidak boleh terlalu cepat memberikan label kepada anak tersebut sebagai seorang "Penjahat" atau label apa saja yang bisa membuat anak tersebut tidak nyaman dalam berinteraksi sosial, karena pada dasarnya anak tersebut adalah korban dari sebuah sistem sosial yang diakibatkan oleh beberapa faktor seperti faktor lingkungan dan sosial yang tidak sehat.

Meskipun hukum pidana menjadi legitimasi untuk mengurangi dan membatasi penikmatan hak asasi seseorang, namun terdapat sejumlah hak dan kebebasan yang tidak boleh dikurangi dalam kondisi apapun. Sejumlah hak ini di kenal dengan hak-hak non derogable, yaitu hak-hak yang bersifat absolut yang tidak boleh dikurangi pemenuhannya oleh Negara, walaupun dalam keadaan darurat sekalipun. Terkait dengan seseorang yang berkonflik dengan hukum: (1) Hak atas hidup; (2) Hak bebas dari penyiksaan; (3) Hak bebas dari pemidanaan yang berlaku surut; dan (3) Hak sebagai subyek hukum, termasuk hak non derogable (Pasal 4 ayat (2) Kovenan Hak Sipil dan Hak Politik).

Dalam hal upaya pembinaan dan perlindungan anak, dihadapkan pada permasalahan dan tantangan dalam masyarakat dan kadang-kadang dijumpai penyimpangan perilaku di kalangan anak, bahkan anak yang melakukan perbuatan melanggar hukum, tanpa mengenal status sosial dan ekonomi. Dalam penanganan kasus-kasus kenakalan anak menurut sistem Peradilan Pidana Anak (Juvenile Justice System) melibatkan segala unsur sistem peradilan pidana antara lain: (1). 
Polisi merupakan institusi ketika anak nakal pertama kali bersentuhan dengan sistem peradilan, yang akan menentukan apakah anak akan dibebaskan atau di proses lebih lanjut; (2). Jaksa dan lembaga pembebasan bersyarat yang juga akan menentukan apakah anak akan dibebaskan atau di proses ke pengadilan anak; (3). Pengadilan Anak, tahapan ketika anak akan ditempatkan dalam pilihan-pilihan, mulai dari dibebaskan sampai dimasukkan dalam institusi penghukuman; dan (4), institusi penghukuman. ${ }^{13}$

Untuk lebih memantapkan upaya pembinaan dan pemberian bimbingan bagi anak nakal yang telah di putus oleh Hakim, maka anak tersebut di tampung di Lembaga Pemasyarakatan Anak. Berbagai pertimbangan tersebut di atas serta dalam rangka mewujudkan peradilan yang memperhatikan perlindungan dan kepentingan anak, maka perlu di atur ketentuan-ketentuan mengenai penyelenggaraan pengadilan yang khusus bagi anak dalam lingkungan Peradilan Umum. Dengan demikian Pengadilan Anak diharapkan dapat memberikan arah yang tepat dalam pembinaan dan perlindungan terhadap anak.

\section{II.4 Penanganan Perkara Pidana Berdasarkan Ketentuan Hukum Acara}

\section{Pidana}

Menurut Susilo Yuwono, penyelenggaraan administrasi perkara pidana menurut Kitab Undang-Undang Hukum Acara Pidana (KUHAP) berjalan atas tahap-tahap:

1. Penyelidikan dan/ atau penyidikan;

2. Penuntutan;

3. Pemeriksaan sidang Pengadilan;

4. Upaya hukum (sepanjang hal ini diminta oleh pihak yang bersangkutan);

5. Pelaksanaan putusan pengadilan yang telah mempunyai kekuatan hukum tetap. $^{14}$

\footnotetext{
${ }^{13}$ Purnianti, Mamik Sri Supatmi, dan Ni Made Martini Tinduk, Analisa Situasi Sistem Peradilan Pidana Anak (Juvenile Justice System) di Indonesia, (Indonesia: UNICEF, 200)., hlm.72

${ }^{14}$ Susilo Yuwono, Penyelesaian Perkaran Pidana Berdasarkan KUHAP Sistem dan Prosedur, Bandung: Alumni, 1982, hlm.29
} 
Sesuai dengan pentahapan tersebut, maka diadakan pembagian tugas dan wewenang di antara para pelaksana penegak hukum. Pembagian tugas dan wewenang ini menurut Susilo Yuwono, merupakan langkah untuk menertibkan badan-badan penegak hukum sesuai fungsi dan wewenangnya masing-masing. Tetapi pembagian fungsi dan wewenangan dalam rangka acara pidana ini tidaklah bersifat pemidahan sehingga satu sama lain berdiri sendiri-sendiri. Melainkan antara yang satu dan lainnya saling berhubungan erat, sehingga secara fungsional, penyelenggaraan acara pidana oleh badan-badan pelaksana hukum marupakan satu sistem yang saling menunjang. Dalam seluruh sistem itu pada akhirnya bermuara pada "kepastian hukum, kebenaran dan keadilan". ${ }^{15}$

\section{II.5 Pelaksanaan Pembinaan Anak Yang Berkonflik dengan Hukum di Wilayah Hukum Jakarta Selatan}

Wilayah hukum Polres Jakarta Selatan memiliki karateristik tersendiri sebagai wilayah pusat pemerintahan dan kegiatan masyarakat, baik yang bersifat Nasional, Regional maupun Internasional. Dari 2 kecamatan di Jakarta Selatan, kawasan Kebayoran Lama merupakan tergolong rawan. Tahun 2005 ada 642 kasus, yang antara lain adalah perampokan nasabah bank dan kasus uang palsu. Urutan kedua berada di Kebayoran Baru sebanyak 562 kasus, yang antara lain peledakan bom dan perampokan nasabah bank. Urutan ketiga Jagakarsa ada 512 kasus. Pasar Minggu sebanyak 397 kasus yang antara lain pembunuhan dan Tebet 352 kasus yang antara lain perampokan nasabah bank. Undang-Undang Nomor 11 Tahun 2012 tentang SPPA yang seharusnya sudah berlaku 2 (dua) tahun sejak tanggal diundangkan, 30 Juli 2012, ternyata masih menyisakan banyak catatan minus terkait dengan implementasinya, bahkan di tataran para penegak hukum sekalipun. Polisi, sebagai institusi yang pertama kali bersentuhan dengan perkara Anak Berkonflik Hukum (ABH).

Setiap penanganan perkara $\mathrm{ABH}$ di tingkat Kepolisian di wilayah DKI Jakarta harus selalu mengedepankan pendekatan diversi dan keadilan restorasi (restorative justice) setelah semua proses penyidikan, penyelidikan, hingga

${ }^{15}$ Ibid. 
ditetapkannya anak sebagai tersangka. Pada setiap wilayah institusi Kepolisian setingkat Polres di wilayah Provinsi DKI Jakarta, pada dasarnya sudah memiliki penyidik khusus anak yang bernaung di bawah Unit Perlindungan Perempuan dan Anak (Unit PPA), dengan ruang lingkup proses penyelesaian perkara $\mathrm{ABH}$, terhitung sejak dilakukannya Hukum Acara Pidana Penyidikan (HAP-Sidik) sampai dengan Hukum Acara Pembimbingan (HAP-Bimbing) setelah anak selesai menjalani proses pidana. Dalam setiap pelaksanaan penanganannya, pihak Kepolisian selalu mengupayakan kerjasama dengan melibatkan para pihak terkait, untuk dapat mencari solusi terbaik sebagai bagian dari pertimbangan pendapat untuk penanganan $\mathrm{ABH}$ di tingkatan kepolisian.

Para pihak yang seringkali dilibatkan dalam setiap penanganan perkara $\mathrm{ABH}$ oleh polisi, antara lain: Balai Pemasyarakatan (BAPAS), Departemen Sosial RI, Komisi Nasional Perlindungan Anak (KOMNAS ANAK), Komisi Perlindungan Anak Indonesia (KPAI), Lembaga Bantuan Hukum (LBH), maupun para pakar hukum terkait.

Tidak adanya anggaran yang khusus diperuntukkan bagi penuntasan penanganan perkara $\mathrm{ABH}$ menjadi masalah klasik yang belum juga berujung hasil. Sejauh ini, alokasi penganggaran penanganan perkara $\mathrm{ABH}$ masih diambilkan dari anggaran teknis umum penyidikan sehingga tidak bisa optimal membangun kerjasama antara lembaga terkait penanganan perkara $\mathrm{ABH}$. "Bagaimana bisa leluasa mengundang PK dari Bapas untuk mendampingi $\mathrm{ABH}$ kalau anggarannya aja nggak ada."

Belum tersedianya sarana khusus bagi tahanan anak yang sesuai dengan bunyi UU No.11/2012, juga menjadi momok yang kerap menyulitkan kerja Polisi. Panti sosial hampir selalu dijadikan institusi rujukan sebagai tempat penitipan $\mathrm{ABH}$ setelah terjadinya kesepakatan diversi. Pasalnya, belum ada peraturan teknis yang mengatur tentang fungsi Lembaga Penyelenggaraan Kesejahteraan Sosial (LPKS) secara jelas dan terang.

Terbatasnya pemahaman Polisi terkait bunyi UU SPPA, berkolerasi sangat erat dengan sedikitnya kesempatan bagi para petugas penyidik anak untuk bisa menjalani proses pendidikan dan pelatihan peningkatan kapasitas Polisi dalam 
pelaksanaan penanganan $\mathrm{ABH}$. Hal ini tentunya juga berimbas pada minimnya penyidik anak yang bersertifikat di lingkungan institusi kepolisian. Dari total jumlah petugas unit PPA di Polres yang ada di wilayah Jakarta saja, misalnya, jumlah penyidik anak yang bersertifikat masih belum genap setengahnya.

\section{II.6 Konstruksi Hak-hak Anak Yang Berhadapan Dengan Hukum}

Sebelum penulis menguraikan mengenai hak-hak anak yang berhadapan dengan hukum, terlebih dahulu penulis jelaskan pemahaman tentang "Konstruksi", dan definisi "Anak yang berhadapan dengan hukum". Hal ini di kandung maksud untuk menghindari perbedaan persepsi antara pembaca dengan penulis.

Istilah "Konstruksi” merupakan istilah teknik yang menunjukkan pada suatu susunan, bentuk/model/tata letak. Konstruksi yang penulis maksudkan disini adalah susunan pola ketentuan atau rumusan peraturan perundang- undangan yang mengatur mengenai hak-hak anak yang berhadapan dengan hukum $(\mathrm{ABH})$.

Dalam konsideran Undang-Undang Nomor 11 Tahun 2012 tentang Sistem Peradilan Pidana Anak disebutkan, anak adalah bagian dari generasi muda sebagai salah satu sumber daya manusia yang merupakan potensi yang memiliki peranan strategis dan mempunyai ciri dan sifat khusus, memerlukan pembinaan dan perlindungan dalam rangka menjamin pertumbuhan dan perkembangan fisik, mental, dan sosial secara utuh, serasi, selaras, dan seimbang. Dalam pelaksanakan pembinaan dan memberikan perlindungan terhadap anak, diperlukan dukungan, baik yang menyangkut kelembagaan maupun perangkat hukum yang lebih mantap dan memadai, oleh karena itu ketentuan mengenai penyelenggaraan pengadilan bagi anak perlu dilakukan secara khusus.

Dalam hal penahanan terhadap anak, Undang-Undang Nomor 11 Tahun 2012 tentang Sistem Peradilan Pidana Anak menentukan secara umum lama pelaksanaan penahanannya ditentukan sesuai dengan kepentingan anak dan pembedaan ancaman pidana bagi anak yang ditentukan oleh Kitab Undang-Undang Hukum Pidana yang penjatuhan pidananya ditentukan 1/2 (satu per dua) dari maksimum ancaman pidana yang dilakukan oleh orang dewasa, dan tidak berlaku pada anak terhadap penjatuhan pidana mati dan pidana penjara seumur hidup. 
Pembedaan perlakuan dan ancaman yang diatur dalam Undang- Undang ini dimaksudkan untuk lebih melindungi dan mengayomi anak tersebut agar dapat menyongsong masa depannya yang masih panjang. Pembedaan tersebut dimaksudkan untuk memberi kesempatan kepada anak agar melalui pembinaan akan diperoleh jati dirinya untuk menjadi manusia yang mandiri, bertanggungjawab, dan berguna bagi diri, keluarga, masyarakat, bangsa dan negara dan pembedaan perlakuan tersebut didasarkan atas pertumbuhan dan perkembangan fisik, mental, dan sosial anak.

Penahanan terhadap anak dilaksanakan di tempat khusus untuk anak di lingkungan Rumah Tahanan Negara, Cabang Rumah Tahanan Negara, atau ditempat tertentu. Kewenangan untuk penahanan ini tidak serta merta, artinya harus terdapat alasan-alasan yang didasarkan pada penilaian dengan sungguh-sungguh mempertimbangkan kepentingan anak dan atau kepentingan masyarakat, dan hal ini harus dinyatakan secara tegas dalam surat perintah penahanan. Hak anak yang dikenakan upaya paksa penahan, maka tempat tahanan anak harus dipisahkan dari tempat tahanan orang dewasa, dan selama anak ditahan, kebutuhan jasmani, rohani, dan sosial anak harustetap dipenuhi.

Di samping itu, anak yang di tahan mempunyai hak sejak saat di tangkap atau ditahan berhak mendapatkan bantuan hukum dari seorang atau lebih Penasihat Hukum selama dalam waktu dan pada setiap tingkat pemeriksaan. Kewajiban dari penyidik yang telah melakukan penahanan adalah wajib memberitahukan kepada tersangka dan orang tua, wali, atau orang tua asuh, mengenai hak memperoleh bantuan hukum. Adanya kewajiban ini terkait erat dengan hak anak yang di tangkap atau di tahan berhak berhubungan langsung dengan Penasihat Hukum dengan diawasi tanpa didengar oleh pejabat yang berwenang.

Di dalam Undang-Undang Perlindungan Anak terdapat berbagai aturan/ketentuan yang berkaitan dengan hak-hak anak yang berhadapan dengan permasalahan hukum bahwa (1). Setiap anak berhak untuk memperoleh perlindungan dari sasaran penganiayaan, penyiksaan, atau penjatuhan hukuman yang tidak manusiawi; (2). Setiap anak berhak memperoleh kebebasan sesuai dengan hukum; dan (3). Penangkapan, penahanan, atau tindak pidana penjara anak 
hanya dilakukan apabila sesuai dengan hukum yang berlaku dan hanya dapat dilakukan sebagai upaya terakhir.

Untuk menjamin Perlindungan terhadap anak-anak yang berhadapan dengan hukum ditetapkan sebagai kelompok anak yang membutuhkan "Perlindungan Khusus". Menurut Undang-Undang Perlindungan Anak (UU Pasal 64 meliputi anak yang berkonflik dengan hukum dan anak korban tindak pidana. Bentuk perlindungan khusus tersebut meliputi:

1. Penyediaan petugas pendamping khusus bagi anak sejak dini;

2. Penyediaan sarana dan prasarana khusus;

3. Penjatuhan sanksi yang tepat bagi anak;

4. Pemantauan terus menerus terhadap perkembangan anak yang berhadapan dengan hukum;

5. Pemberian jaminan untuk mempertahankan hubungan dengan orang tua atau keluarga;

6. Perlindungan dari pemberitaan identitas dan untuk menghindari labelisasi.

Persoalan hukum tidak hanya menimpa orang-orang dewasa. Anak-anak juga seringkali terbentur dengan persoalan hukum dan seperti halnya orang dewasa, anak-anak juga berhak mendapat perlindungan secara hukum. Perlindungan hukum ini tidak hanya diberikan kepada anak yang menjadi korban dalam suatu maasalah hukum, tapi juga kepada anak-anak yang menjadi pelakunya.

Peradilan anak itu berada di bawah peradilan umum, yang diatur secara istimewa dan undang-undang pengadilan anak hanyalan masalah acara sidangnya yang berbeda dengan acara siding bagi orang dewasa. Pengadilan anak ada pada badan peradilan umum.

\section{II.7 Pelaksanaan Hak-Hak Tersangka Anak Yang Berhadapan dengan Hukum (ABH)}

Dengan berlakunya UU SPPA, penyelesaian kasus pidana anak harus diupayakan melalui diversi dan restorative justice. Putusan pidana sebagaimana 
diatur dalam Pasal 71 Ayat 1 huruf a, b dan c UU SPPA tentang Pidana pokok bagi Anak terdiri atas:

1. Pidana peringatan;

2. Pidana dengan syarat:

1) Pembinaan di luar lembaga;

2) Pelayanan masyarakat; atau

3) Pengawasan

3. Pelatihan kerja;

4. Pembinaan dalam lembaga; dan

5. Penjara

Jenis-jenis pidana Anak tersebut merupakan hasil akhir yang diharapkan apabila anak terpaksa harus berhadapan dengan proses peradilan. Implementasi maksimal dari UU SPPA diharapkan mampu mengurangi anak yang harus ditempatkan di lapas atau rutan yang nantinya akan berganti nama dan fungsinya sebagai LPKA dan Lembaga Penempatan Anak Sementara (LPAS).

Berdasarkan hasil penelitian dan pengamatan penulis, terdapat beberapa faktor penyebab terjadinya kejahatan/pelanggaran yang dilakukan oleh anak, diantaranya adalah faktor keluarga, faktor lingkungan dan faktor ekonomi. Dari ketiga faktor tersebut, bisa ketiganya sekaligus menjadi faktor penyebab atau hanya salah satunya saja.

1. Faktor keluarga.

2. Faktor lingkungan.

3. Faktor ekonomi

Ketiga faktor di atas, hanyalah sebagian dari pemicu anak melakukan pelanggaran hukum. Perlu perhatian yang serius oleh tiga institusi pendidikan anak, yaitu keluarga, sekolah dan lingkungan. 


\section{II.8 Alternatif Penghukuman Sebagai Implementasi Hak-hak Anak Dalam Tindak Pidana Anak}

Digunakannya istilah "alternatif" dalam sub-bab uraian ini untuk menunjukkan bahwa harus atau telah ada cara/bentuk lain selain dengan menggunakan sanksi pidana untuk memberikan hukuman terhadap anak yang melakukan tindak pidana/kejahatan. Hal ini mengingat dalam perkembangan hukum pidana, khususnya hukum pidana di Indonesia, locus pembicaraan tidak hanya pada seputar kriminalisasi dan dekriminalisasi, melainkan telah berkembang pada urgensi pemidanaan itu sendiri yang lebih spesifik pada eksistensi sanksi pidana. Banyak pihak utamanya para pakar hukum pidana dalam melakukan content analisis urgensi sanksi pidana, telah "keluar" dari teori sanksi pidana sebagai pembalasan, dengan mengusung konsep baru dimana sanksi pidana ini dimaksudkan untuk memperbaiki/restorasi.

Melihat realitas tersebut, terlahir suatu niatan yang komprehensif untuk memberikan perilindungan terhadap anak yaitu sistem peradilan pidana yang "ramah" anak, dimana secara substansial yang di atur dalam Undang-Undang Nomor 11 Tahun 2012 tentang Sistem Peradilan Pidana Anak (SPPA), antara lain, Mengenai penempatan Anak yang menjalani proses peradilan dapat ditempatkan di Lembaga Pembinaan Khusus Anak (LPKA).

Substansi yang paling mendasar dalam Undang-Undang Nomor 11 Tahun 2012 tentang Sistem Peradilan Pidana Anak adalah pengaturan secara tegas mengenai Keadilan Restoratif dan Diversi. Keadilan restoratif dan diversi ini dimaksudkan untuk menghindari dan menjauhkan anak dari proses peradilan sehingga dapat menghindari stigmatisasi terhadap anak yang berhadapan dengan hukum dan diharapkan anak dapat kembali kedalam lingkungan sosial secara wajar.

Proses itu harus bertujuan pada terciptanya keadilan restoratif, baik bagi anak maupun bagi korban makanya perlu suatu proses diversi karena semua pihak yang terlibat dalam suatu tindak pidana tertentu secara bersama mengatasi masalah serta menciptakan suatu kewajiban untuk membuat segala sesuatunya menjadi lebih baik dengan melibatkan korban, anak, dan masyarakat dalam mencari solusi untuk 
memperbaiki, rekonsiliasi, dan menenteramkan hati yang tidak berdasarkan pembalasan.

Berdasarkan pada ketentuan Pasal 5 Undang-Undang Nomor 11 Tahun 2012 tentang Sistem Peradilan Pidana Anak di atas, jelas terlihat bahwa restoratif itu merupakan suatu konsep atau model dalam sistem peradilan untuk mendistribusikan keadilan terhadap pihak-pihak yang ingin memperoleh keadilan. Konsep resotarif dalam sistem peradilan pidana anak ini dilakukan dengan cara diversi.

Pada Pasal 1 angka (7) dalam UU SPPA, bahwa Diversi adalah pengalihan penyelesaian perkara Anak dari proses peradilan pidana ke proses di luar peradilan pidana. Diversi adalah pengalihan proses pada sistem penyelesaian perkara anak yang panjang dan sangat kaku. Mediasi/musyawarah sebagai bagian yang tidak terpisahkan dalam diversi untuk mencapai keadilan restoratif. Tujuan dari diversi adalah:

1. Mencapai perdamaian antara korban dan Anak;

2. Menyelesaikan perkara Anak di luar proses peradilan;

3. Menghindarkan Anak dari perampasan kemerdekaan;

4. Mendorong masyarakat untuk berpartisipasi; dan

5. Menanamkan rasa tanggung jawab kepada Anak.

Diversi wajib diupayakan dalam semua tingkat sub sistem peradilan pidana. Hal ini sebagaimana ditentukan di dalam Pasal 7, dimana, "Pada tingkat penyidikan, penuntutan, dan pemeriksaan perkara Anak di pengadilan negeri wajib diupayakan Diversi.

\section{II.9 Keterbatasan Fasilitas}

Dalam pelaksanaan pembinaan anak yang berkonflik dengan hukum,penegak hukum berhadapan dengan beberapa kendala ${ }^{16}$ sebagai berikut :

\footnotetext{
${ }^{16}$ Nurini Aprilianda dan Tim Pengkaji Hukum, Hasil Laporan Akhir Pengkajian Hukum Tentang Model Pembinaan Anak Berbasis Pendidikan Layak Anak Dalam Sistem Pemasyarakatan, Pusat
} 
1. Minimnya Rutan / Lapas Anak (LPA). Ketersediaan 19 lapas anak tidak memenuhi kebutuhan 33 Provinsi di Indonesia, bahkan rumah tahanan (rutan) khusus anak pun tidak ada sama sekali. Padahal kondisi ini berdampak pada terpaksa harus bercampurnya Anak dengan orang dewasa di Lapas Dewasa. Bahkan jumlah anak yang berada di lapas dewasa lebih banyak daripada anak yang ditempatkan di lapas khusus anak.

2. Kondisi Bangunan. Penyelenggaraan pendidikan bagi Anak di Lapas Anak sangat dipengaruhi salah satunya adalah tempat diselenggarakannya pendidikan. Anak yang ditempatkan di dalam lapas/ rutan, tentunya memilki kondisi psikologis yang jauh berbeda dengan anak pada umumnya.

Saat ini LPKA yang ada belum bisa dikatakan siap sepenuhnya untuk pelaksanaan berlakunya UU SPPA, khususnya dalam kesiapan bangunan yang ramah Anak untuk pembinaan, pelayanan dan juga pendidikan, walaupun ada rentang waktu 5 (lima) tahun yang diberikan oleh UU SPPA.

\section{II.10 Sarana Penunjang Pelaksanaan Pendidikan}

Pada umumnya Lapas belum memiliki sarana dan prasarana yang memadai untuk mendukung kegiatan belajar mengajar seperti ruang kelas, fasilitas belajar, kurikulum yang belum sesuai dengan kebutuhan anak, belum adanya harmonisasi regulasi misalnya adanya standar Diknas sebagai syarat untuk peserta didik mengikuti pendidikan kesetaraan harus memenuhi quota yang ditentukan oleh Dinkas. Untuk paket A (20 orang), paket B (25 orang) dan paket C (30 orang). Hal ini menjadi salah satu faktor penghambat karena quota tersebut tidak dapat dipenuhi mengingat jumlah anak yang mengikuti pendidikan sedikit.

Hasil pemetaan lapas-lapas anak pada tahun 2011 dan 2012 yang dilakukan jajaran Ditjen PAS menjabarkan bahwa secara umum sarana prasarana yang dimiliki sangat minim dan belum memenuhi kebutuhan pelaksanaan. Sarana penunjang yang paling utama adalah ketiadaan atau minimnya fasilitas ruang

Penelitian dan Pengembangan Sistem Hukum Nasional Badan Pembinaan Hukum Nasional Kementerian Hukum dan Hak Asasi Manusia RI, 2014 
belajar untuk pelaksanaan program kesetaraan Ketiadaan ruang khusus untuk belajar, menjadikan ruangan tertentu mempunyai fungsi ganda. Misalnya seperti di Lapas Anak Gianyar, proses belajar dilakukan di Aula, di Lapas Anak Muara Bulian proses belajar dilakukan di perpustakaan.

Beberapa sarana prasaran penting selain ruang belajar yang juga minim sebagai pendukung penyelenggaraan pendidikan, seperti alat-alat belajar, computer, LCD, seragam dan lain-lain. Kebutuhan di setiap lapas anak secara umum sama, walaupun terdapat beberapa perbedaan di beberapa bagian.

\section{II.11 Anggaran}

Anggaran pada DIPA khusus untuk pelaksanaan pendidikan tidak ada serta minimnya dana untuk perbaikan sarana prasarana yang pada sebagian besar lapas anak perlu perbaikan, bahkan renovasi total. Seperti di Lapas Anak Kotabumi Lampung yang pernah mengalami kebakaran pada tahun 2012 yang hampir menghabiskan seluruh fasilitas lapas, minimnya anggaran pemerintah untuk pembangunan LPKA baru, bukan hanya untuk LPKA, tetapi juga lapas dewasa. Kondisi ini mengakibatkan beberapa LPKA difungsikan juga sebagai lapas untuk orang dewasa. Seperti di LPKA Tomohon Sulawesi Utara yang tidak hanya ditempati anak, tetapi juga penghuni dewasa pria dan wanita. Di LPKA Kotabumi Lampung, LPKA Pekanbaru dan LPKA Wanita Tangerang, anak harus berbagi tempat dengan wanita dewasa, bahkan seperti di LPKA Wanita Tangerang jumlah hunian dewasa jauh lebih banyak daripada anak.

Minimnya anggaran untuk pelaksanaan monitoring dan evaluasi pelaksanaan pembinaan pendidikan di Ditjen PAS, khususnya di LPKA. 19 lapas anak yang tersebar di Indonesia seharusnya dilakukan pengawasan dan evaluasi serta pemetaan setiap tahun secara berkelanjutan. Letak lapas anak yang berada di beberapa wilayah Indonesia membuat biaya evaluasi monitoring dan pemetaan menjadi relatif tinggi, namun ini diperlukan untuk mengetahui sejauh mana kegiatan pelaksanaan pembinaan pendidikan dan kendala permasalahan yang nyata di lapangan. 


\section{II.12 Sumber Daya Manusia (SDM)}

Sumber Daya Manusia yang dalam hal ini adalah petugas LPKA yang bertanggung jawab pada pelaksanaan pembinaan anak, yang salah satunya adalah pendidikan. Secara kuantitas sebenarnya SDM yang ada termasuk cukup memadai, khususnya jika dibandingkan dengan kodisi lapas dewasa yang rasio pegawai dengan hunian sangat tidak seimbang dengan jumlah hunian. Menurut data dari Ditjen PAS, rasio pegawai lapas anak dengan anak di lapas anak adalah sekitar 2 : 1 (jumlah pegawai 903 berbading 1435 anak). Data ini hanya terbatas pada rasio pegawai dan anak di lapas anak, belum melingkupi anak dan pegawai yang berada di lapas dewasa. Di atas kertas, secara kuantitas seharusnya tidak menjadi masalah berarti, apalagi untuk hunian anak, ditinjau dari sisi keamanan memiliki risiko yang lebih rendah daripada dewasa. Dengan kondisi ini seharusnya lagi pembinaan anak lebih bisa terkonsentrasi. Namun pada kenyataannya masih sangat sulit untuk mencapai hasil maksimal pendidikan anak, apalagi lapas anak yang fungsinya bercampur untuk hunian dewasa.

\section{III.PENUTUP}

\section{Kesimpulan}

1. Sistem peradilan pidana anak telah mengkonstruksi hak-hak anak yang berhadapan dengan hukum $(\mathrm{ABH})$ yaitu dengan tidak lagi diposisikannya anak sebagai objek dengan tujuan agar dapat terwujud peradilan yang benar-benar menjamin pelindungan kepentingan terbaik terhadap anak yang berhadapan dengan hukum sebagai penerus bangsa.

Dalam penerapan prinsip mengutamakan kepentingan terbaik bagi anak, diperlukan proses penyelesaian perkara anak di luar mekanisme pidana atau biasa disebut diversi, dengan pendekatan keadilan restorasi. Mekanisme diversi dilakukan dalam semua jenjang peradilan pidana anak (dimulai dalam tahap penyelidikan/penyidikan di Kepolisian, diversi bisa juga dilakukan pada saat penuntutan, pada saat di Pengadilan, dan diversi bisa dilakukan pada saat tahap pelaksanaan putusan). 
2. Kendala-kendala yang dihadapi dalam pelaksanaan pembinaan anak yang berkonflik dengan hukum:

a) Keterbatasan fasilitas; 1). Minimnya Rutan / Lapas Anak (LPA); dan 2). Kondisi bangunan yang tidak memadai

b) Minimnya sarana penunjang pelaksanaan pendidikan;

c) Anggaran yang minim;

d) Keterbatasan sumber daya manusia.

\section{Saran}

Berdasarkan kesimpulan di atas, penulis menyarankan:

1. Pada prinsipnya memang dalam sistem peradilan pidana anak adalah untuk melindungi kepentingan dan menjungjung tinggi harkat martabat anak. Tetapi demikian, penulis menyarankan agar penegak hukum selektif dalam penyelesaian perkara melalui mekansime diversi, yaitu terhadap anak yang melakukan kejahatan berat, residivis, penyelesaian melalui mekanisme akan dirasa tidak adil mengingat kepentingan korban;

2. Dalam hak anak digunakan sebagai alat oleh orang dewasa, sekali pun itu adalah kejahatan berat, maka penulis menyarankan agar mekanisme penyelesaian perkaranya melalui proses diversi. Misalnya anak di eskploitasi oleh orang-orang dewasa dijadikan sebagai pengedar atau kurir narkoba;

\section{DAFTAR PUSTAKA}

\section{Buku}

Astuti, Made Sadhi, Pemidanaan Terhadap Anak Sebagai Pelaku Tindak Pidana. Basah, Sjachran, Tiga Tulisan Tentang Hukum, Bandung: Armico, 1985.

Barda Nawawi Arief, Bunga Rampai Hukum Pidana, Bandung: Alumni, 1992. Bunga Rampai Kebijaksanaan Hukum Pidana, Bandung: Citra Aditya Bakti, 1996. 
Herlina, Apong, et al., Perlindungan Terhadap Anak Yang Berhadapan Dengan Hukum, Manual Pelatihan Untuk Polisi, Jakarta: UNICEF, 2004.

Mochtar Kusumaatmadja dan Arief Sidarta, Pengantar Ilmu Hukum Suatu Pengenalan Pertama Ruang lingkup Berlakunya Ilmu Hukum, Bandung: Alumni, 2000.

Muladi dan Barda Nawawi Arief, Teor-teori dan Kebijakan Pidana, Bandung: Alumni, 1998, hlm.197.

Kusuma, Mulyana W. (Penyunting), Hukum dan Hak-Hak Anak, Jakarta: Rajawali, 1986.

Purnianti, Mamik Sri Supatmi, dan Ni Made Martini Tinduk, Analisa Situasi Sistem Peradilan Pidana Anak (Juvenile Justice System) di Indonesia, Indonesia: UNICEF, 2003

Rahardjo, Satjipto, Keadaan dan permasalahan Penegakan Hukum Dewasa ini, Majalah Masalah-masalah Hukum, Semarang: UNDIP, No.4 Tahun XIII, 1983,

Soemitro, Irma Setyowati, Aspek Hukum Perlindungan Anak, Jakarta: Bina Aksara, 1990

Yuwono, Susilo, Penyelesaian Perkaran Pidana Berdasarkan KUHAP Sistem dan Prosedur, Bandung: Alumni, 1982

Tim Pengajar PIH-FH-UNPAR, Pengantar Ilmu Hukum, Bandung: UNPAR, 1995

\section{Peraturan Perundang-Undangan}

Republik Indonesia, Undang-Undang Nomor 35 Tahun 2014 tentang Perubahan Atas Undang-Undang Nomor 23 Tahun 2002 tentang Perlindungan Anak.

Peradilan Pidana Anak

\section{Jurnal, Makalah, Hasil Penelitian dan Website}

Dellyana, Hak-hak Anak Antara Realita dan Harapan, http://www.yahoo.com, di akses, 12 Juni 2015

Muladi, Penegakan Hukum dan Keadilan melalui Upaya Peraturan Hukum, Makalah dalam Seminar Penegakan Hukum dan Masalahnya, Semarang: Unissula, 1988

Nurini Aprilianda dan Tim Pengkaji Hukum, Hasil Laporan Akhir Pengkajian Hukum Tentang Model Pembinaan Anak Berbasis Pendidikan Layak Anak Dalam Sistem Pemasyarakatan, Pusat Penelitian dan Pengembangan Sistem Hukum Nasional Badan Pembinaan Hukum Nasional Kementerian Hukum dan Hak Asasi Manusia RI, 2014 
Yohana Yembise, Menteri Pemberdayaan Perempuan dan Perlindungan Anak, Jumlah Anak Berhadapan Dengan Hukum Meningkat, Antaranews.com, Selasa, 28 April 2015 